\title{
Roman Roads
}




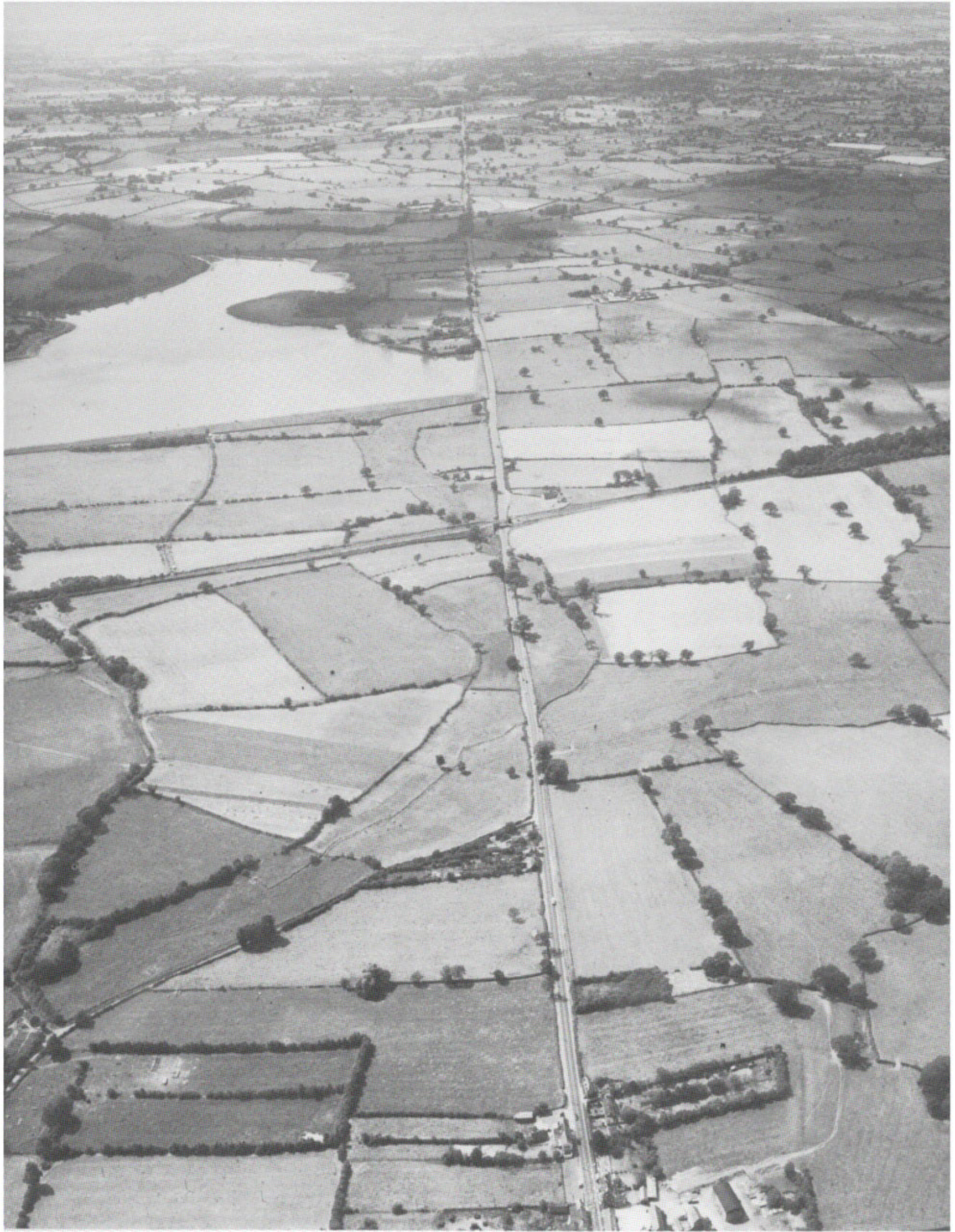

Frontispiece Aerial view of Watling Street west of Pennocrucrum, taken by Arnold Baker 


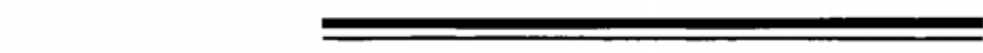

Roman Roads

RAYMOND CHEVALLIER

Director of School of Latin Studies, University of Tours

Translated by N. H. Field

University of California Press

Berkeley and Los Angeles 1976 
First published in this edition 1976

Raymond Chevallier

Translation (C) B. T. Batsford Ltd 1976

University of California Press

Berkeley and Los Angeles, California

ISBN 0-520-02834-I

Library of Congress Catalog Card Number 74-82845

Printed in Great Britain 